\title{
Pedagogia da Morte: Aprender a morrer
}

\section{Resumo}

\section{Poliana Murer Cavalcante Doi (IC)}

O objetivo desta pesquisa foi buscar discussões filosóficas sobre o aprendizado da própria morte. Considerando alguns aspectos históricos, sociais e culturais dessa questão ao longo dos tempos - a Contemporaneidade (séculos XIX-XXI), a Modernidade (séculos XVI-XVIII) e a Antiguidade (séculos VIII a.C.-V d.C.) - o trabalho debruçou-se sobre discursos que apontam para o afastamento de um (auto)conhecimento que envolva a condição humana e a realidade da morte, o que se reflete num desconhecimento - e mesmo num desprezo - da própria vida como meio e expressão do que se tem na conta de genuinamente humano. Considera-se que esse estudo possa contribuir para uma compreensão desse humano que aprende a morrer, sugerindo caminhos para uma vida plena.

Palavras Chave: Morte, Pedagogia, Ideal Humano.

\section{Introdução}

Ter domínio do conhecimento sobre a vida e sobre a morte remete a uma educação mais humana e mais justa, tanto pelo viés do confronto com as desigualdades sociais quanto pela perspectiva ou esperança de supressão do medo, possibilitando consequentemente a busca de superação do tabu da morte. Para a "pedagogia da morte", o aprender a morrer pressupõe e torna possível o conhecimento racional acerca de questões existenciais humanas, constituindo uma proposta pedagógica que tem em vista uma nova mentalidade, na qual o amor e a responsabilidade sejam capazes de sobrepujar a dominação perversa imposta pelos sistemas de poder e controle em que vive a humanidade desde tempos imemoriais. Nesse sentido, o alvo principal do trabalho é o conhecimento sobre a condição humana focado não só no aprendizado da morte e do morrer mas também na postura diante da vida, visando a favorecer exercícios filosóficos pelos quais se assuma a vida com total responsabilidade por ela.

\section{Resultados e Discussão}

$\mathrm{Na}$ Contemporaneidade, Rodrigues ${ }^{1}$ afirma a importância do capitalismo e da religião para a compreensão das questões sobre o domínio da vida e da morte. Já Corrêa ${ }^{2}$ entende que a partir disso geram-se formas perversas de ocultamento da realidade que corroboram o tabu da morte. A leitura desses contemporâneos direcionou então a pesquisa para o exame dos ideais de comportamentos que vão se consolidando mediante as imposições - econômicas e religiosas - de aceitação e resistência no que tange à realidade da morte e de sua relação com a vida. Seguindo para a Modernidade, investigam-se os sentidos que Montaigne ${ }^{3}$ atribui ao aprender a morrer, vendo-se que ele defende que é o saber-se mortal que glorifica a vida e liberta o ser humano da servidão. Por sua vez, com manuais de comportamento, o jesuíta Graciàn ${ }^{4}$ apresenta o "homem universal" e bemsucedido da corte, que domina suas paixões e deve estar sempre pronto para a morte. Já o padre Bonucci $i^{5}$ vai além e prega a obediência, a devoção e a penitência, ou seja, a entrega da vida a Deus. Ao envolver a questão da alma e da pessoa humana, esse percurso conduz à Antiguidade, mais especificamente ao Sócrates narrado por Platão ${ }^{6}$, que enfatiza a ideia de que a dignidade, o respeito e a coragem são atributos de quem aprendeu a morrer.

\section{Conclusões}

Considera-se que aprender a morrer é o mais importante atributo para uma vida plena. Libertarse do tabu da morte é não somente estar pronto para morrer, mas apropriar-se da vida de uma forma a assumi-la em sua plenitude.

\section{Agradecimentos}

O presente trabalho foi realizado com apoio do CNPq.

\footnotetext{
Rodrigues, J. C. Tabu da Morte. Rio de Janeiro: Achiamé, 1983. ${ }^{2}$ Corrêa, J.A. Morte. São Paulo: Globo, 2008.

${ }^{3}$ Montaigne, M. Ensaios. Tradução de S. Milliet. São Paulo: Globo, 1972. p. 48-55. (Os Pensadores, Abril Cultural).

${ }^{4}$ Gracián, B. El Discreto. Eikasia: Revista de Filosofía, II 8 (enero 2007). Disponível em: <revistadefilosofia.com/13Eldiscreto.pdf> Acesso em: 12/09/2015.

${ }^{5}$ Bonucci, A. M., Pe,.Escola de bem morrer. Aberta a todos os Christãos, \& particularmente os da Bahia nos exercicios de piedade, que se practicaõ nas tardes de todos os Domingos pelos Irmãos da Confraria da Boa Morte, instituida com authoridade Apostolica na Igreja do Collegio da Companhia de JESU. Lisboa: Officina de Miguel Deslandes Impressor de Sua Magestade, 1701. Disponível em: <http://purl.pt/14238/4/r-13159-p_PDF/r-13159-p_PDF_24-CR0150/r-13159-p_0000_Obra\%20Completa_t24-C-R0150.pdf> Acesso 23/09/2014.

${ }^{6}$ PLATÃO. Defesa de Sócrates. In: PESSANHA, J. A M.(0rg) Sócrates. Tradução de J. Bruna, L. R. de Andrade e G. M. R. Starzynski. 2. ed . São Paulo: Abril Cultural, 1980 (Os Pensadores).
} 